\title{
An Investigation of the Attitudes of Teachers on the Use of Newspapers in the Teaching of Turkish as a Foreign Language According to Some Variables *
}

\author{
Ertan Miyanyedi ${ }^{1} \&$ Bünyamin Celik $^{2}$
}

\author{
${ }^{1}$ Stirling Education Company, Erbil, Iraq \\ ${ }^{2}$ Department of Languages, Tishk International University, Erbil, Iraq \\ Correspondence: Bünyamin Celik, Tishk International University, Erbil, Iraq. \\ Email: bunyamin.celik@tiu.edu.iq
}

Doi: $10.23918 /$ ijsses.v7i3p130

\begin{abstract}
In recent years, many studies have been conducted on teaching Turkish as a foreign language. While some of these researches involve teaching language skills, some involve developing materials. As well as the materials developed in this field, the beliefs of the language teachers who will apply these materials will affect the use of these developed materials and their benefits to students. One of the materials that can be used in teaching Turkish as a foreign language is newspapers, also considered as authentic materials. In the researches, it has been stated that the classrooms where newspapers are used have positive effects on students' interest and participation in the lesson. As the starting point of this research, it was tried to determine which opinions and attitudes the teachers who teach Turkish to foreigners have towards using newspaper in their lessons. The research was conducted with a descriptive method-based screening model. For this purpose, teachers who teach Turkish abroad were contacted via internet and a questionnaire was conducted with them. In the analysis of the data obtained from the questionnaire, the frequency and percentages of the items were calculated. As a result, it was determined that there was no significant difference of opinion between teachers' views on gender, age, graduated school and experience, and teachers were in agreement that students would participate more actively in the course in the development of vocabulary, development of reading comprehension skills when newspapers are used in lessons. It is thought that this research will be a source for material development studies for the use of newspapers in lessons.
\end{abstract}

Keywords: Foreign Language, Turkish as a Foreign Language, Newspaper, Teachers' Opinions

*It was produced from a doctoral dissertation entitled "Scientific Based Reading and the Effect of Newspapers on Reading Skills in Teaching Turkish as a Foreign Language".

\section{Introduction}

Language, a social and variable tool that consists of sounds, is used to communicate, and has a social aspect (Planc1, 2011). Today, everyone is expected to achieve the desired level of success in the areas of listening-speaking-reading-writing, which we call language skills. Yildiz, (2020) states that a learner needs to be competent in four basic skills to be called a proficient speaker in the target language. Celik and Yildiz (2019) argue that foreign language teaching, which has been felt a need since the beginning of international relations, has become more momentous today. In today's world where societies are intertwined, the mother tongue is not enough, and people learn foreign languages as much as technology allows. The most effective teaching of a foreign language can be provided by dedicated teachers because a committed educator is never content with his / her sharing; rather always looks for the new ideas and methods to be useful to learners (Yildiz \& Celik, 2017; Mart, 2013a; Mart, 2013b). The reasons that push people to learn foreign languages can be considered as education, international policies, trade, tourism, travel for health reasons, 
etc. The main sources used in teaching Turkish as a foreign language include textbooks and additional materials, grammar, reading books appropriate for levels and audio and video supported visual, auditory, or interactive materials.

When the literature is examined, it is stated by the researchers that the competence, visuality and textuality of the textbooks in relation to the basic language skills are the subject of research and that some negativities are encountered in the textbooks (Ulusoy, 2009). While Öztürk (2016) stated that textbooks, as being printed materials, made students passive over time and students' interaction with the material decreased, Hammer (2003, p. 257) stated that "even the best textbooks make studying routine over time for students and they gradually find the books less stimulating". Numan (1988) states that especially "texts written for classroom use somehow spoil the language" (p. 6).

Experts who work in teaching Turkish as a foreign language have some responsibilities to eliminate these problems regarding textbooks and to enable students to learn at the highest level. These specialists should follow developments in education and training and include additional materials and new practices in their lessons. One of the educational materials that has been used frequently in language teaching in recent years is authentic materials. There is little doubt that authentic materials are essential tools for the development of language proficiency (Mart, 2017). Newspapers and magazines come first among authentic materials. According to Hammer (2003, p. 205), authentic material is defined as "texts prepared for general speakers of that language, not for language learners in general".

Although the newspaper can be defined as "a daily or weekly communication tool" in the most general sense, this definition will be incomplete for the newspaper. For this, different definitions have been made for the newspaper. According to Püsküllüoğlu (1994, p. 413) newspaper is a "publication that has a certain number of pages and order, and that contains information about every subject that concerns people, society, politics, economy and culture, and that is published daily or for short periods of time".

Newspapers are the mirror of the world. They are the information sources of society and our close fellows. Newspapers are a common step that can bring the whole world together every morning and bring what is happening in the world to our door together with computers in the modern world (Pillai, 2006).

In addition to the fact that newspapers appeal to the eye, many newspaper articles are featured in news programs today. Newspapers fascinate people with the images they use. In this respect, newspapers have a long effect on people. For many years and even centuries, the newspaper was mentioned as the only tool that formed, shaped, and even changed public opinion. Walter Lipmann, one of the American authors, wrote for the first time in his book on public opinion, "The newspaper is the only book people read every day." (Tokgöz, 1973, p. 83).

Media has very important social functions in societies with developed democracy and these functions can be listed as follows:

- Informing,

- Making audits and criticisms on behalf of the public,

- Enlightening the public and ensuring the free formation of public opinion,

- Education and entertainment (Vural, 2000, pp.105-106). 
İçel (1983) also states that because of developments in the technical and economic fields, the media has assumed the task of education of adult citizens and has become almost an adult school. In the developing and globalizing world, with the effect of technology, most of the people become more interested in the events occurring both at home and abroad. Today, most of the societies show their sensitivity to these developments by following both classical newspapers and print media, as well as newspapers and news bulletins broadcasting on the internet, with the opportunities provided by technology. It is not possible to consider that education does not benefit from these developments in technology. As a result of these developments, the print media is also important in classroom reading activities. From this point of view, reading comes to the fore as a means of obtaining information. The selection of newspaper reading materials suitable for the age and preferences of the students will provide natural input in terms of real life and syntax of the language in classroom reading activities, and reading activities will become more qualified and language associations suitable for daily life will motivate students more. As a result, effective language teaching will be provided. It is thought that course materials prepared from newspapers motivate students more and reflect daily language, and also bring high standards to the language lessons.

\section{The Appearance of Educational Newspapers}

Serin (2017) states that students get satisfied when an educational institution they are in meets or exceeds their expectations. An article published in the Eastern Herald in Portland (Maine) states:

Much has been said and written about newspaper programs so far, but the advantages that can be gained, such as reading newspapers in schools and families with their children, have been neglected in these publications. Do you want your child to improve their reading? Just give him a newspaper. This will drag him into fantasy about some episodes. Do you want him to learn about geography? Thanks to the stories and events published in newspapers, he will have unforgettable memories about different places. Do you want him to learn about public or private business or fashion or news about his country or city? Give him the cheapest book, the newspaper, and he will have fun and get the information in small pieces (Herald, 8 June 1795).

The Association of Newspaper in Education was established in the 1930s under the leadership of the New York Times newspaper. NIE is an education partnership involving schools and the newspaper industry. This cooperative initiative was created in schools to teach the use of newspapers and provide course material on subjects such as history, reading, social sciences, mathematics, economics, composition, journalism, management at all levels. NIE programs started life in the 1930s by using secondary school students. These programs have been published in two-week periods by following the current events and have shown a tremendous expansion today. Initially offering programs for middle school students, NIE now operates from pre-school to college and more advanced. NIE programs go beyond school walls, take place in prisons, public education centers, universities, squares, and English classrooms in foreign countries.

Stone (1988) states that students participating in Newspaper in Education (NIE) programs in America do not have difficulty reading newspapers, they like to read newspapers, their interest in public news has increased and they can become potential newspaper readers in the future. Since newspapers are a communication tool, one of their functions is to provide communication. Although the visual elements in newspapers are also found in other communication tools, the texts of the important news items they contain 
provide the language learner with stylistic and other linguistic study opportunities. Accordingly, it is stated that students' vocabulary will be wider, and their speaking skills will improve in classrooms where newspapers are used as a course tool (Moparthi, 2014). Yildiz (2016) indicates that each learner needs a unique learning environment and it could be provided by extracurricular activities, so newspapers can be considered as a new approach in teaching language skills.

Many NIE programs have been developed since the early 1980s, and most of these programs emphasize literacy in their communities. Many of these programs aim to support the education of young people as well as adults by using newspapers in the family. Some programs also aim to raise public awareness on education-related problems and support these programs (Abbott, 2005).

Today, approximately 600 newspapers, mainly the United States and Canada, three million students, 90,000 teachers and 16 schools participate in NIE programs each year. While the NIE was initially used in the social studies course with the content of current events every two weeks and every Friday, it is now used in every field throughout the academic year (Kossack, 1987). Newton (1985) sees this initiative as a resource that will encourage the use of newspapers as an educational tool and complement of traditional teaching materials.

\section{The Place and Importance of the Newspaper in Teaching Turkish as a Foreign Language}

Newspapers give way to the consolidation of the information acquired in parallel with the information in the textbooks. According to Celik, (2020), it is seriously not easy to motivate students in whole period of lesson. Therefore, it is better to apply some new techniques during the lesson. In this context, newspapers are even more important, with its function of being a daily renewed resource for language skills acquisition. In this way, newspapers can be kept in the classroom or within the framework of the scientificbased reading approach given to students, students can follow news or research series and stories in the country where the target language is spoken, either by purchasing the newspaper or by following the internet in other countries where the target language is being learned. They can also improve their writing skills by writing the summary of the event.

Street (2002) states that when using newspapers in lessons, it will help students to develop their reading skills, critical thinking skills and problem-solving skills. Haim (2018) lists the benefits of using newspapers in foreign language classes as follows:

- Students will be exposed to more target languages through newspapers,

- It will cause a meaningful and interesting communication between teacher-student, student-student,

- It will increase motivation as it will attract everyone's attention due to the variety of information and text,

- It will encourage students to adopt different strategies to access information,

- It will encourage students to communicate with the outside world and enrich their knowledge about other cultures and societies,

- It will help them acquire all the skills naturally in the target language, thus the students will have a judgment about whether they agree with the ideas in the article read,

- It provides materials suitable for task-based education such as presentation, problem solving,

- It will help students learn on their own, so it will provide student autonomy and group work. 
In terms of visual material richness, newspapers offer great opportunities to teachers and students in teaching Turkish to foreigners. A newspaper.

1. Improves students' vocabulary,

2. Keeps teaching activities alive,

3. May be the primary source for basic and vital skills and develop these skills,

4. Contributes to character education,

5. Is cheaper and more up to date than textbooks,

6. Allows cutting, folding, marking, pasting unlike textbooks

7. It is an up-to-date resource that helps students make connections between the theoretical information they learn in the classroom and what is happening in the real world (Deveci, 2005). It is a magical material that provides the reader with the opportunity to travel to different parts of the world with up-to-date information (Carey \& Greenberg, 1991)

8. Due to such features, it is one of the materials that should be consulted in teaching Turkish to foreigners.

\section{Research Methodology}

\subsection{Purpose of the Research}

The aim of this study is to determine the teachers' attitudes towards the use of newspapers in lessons in teaching Turkish as a foreign language according to some variables. For this purpose:

1. What are the teachers' opinions on the use of newspapers in teaching Turkish as a foreign language?

2. Is there a relationship between teachers 'views on the use of newspapers in teaching Turkish as a foreign language and teachers' ages?

3. Is there a relationship between teachers' views on the use of newspapers in teaching Turkish as a foreign language and their experiences?

4. Do teachers' views on the use of newspapers in teaching Turkish as a foreign language differ by gender?

5. Does the use of newspapers in teaching Turkish as a foreign language differ according to the universities where the teachers graduated?

\subsection{Research Method}

This study is a descriptive research. According to Kaptan (1998: 59), descriptive research tries to describe and explain "what" events, objects, entities, institutions, groups, and various fields are. Screening model was used in the research. Screening model is an attempt to determine the past or present state of an event. The event, situation, and person subject to the study are tried to be presented in their own conditions, that is, as they are (Arlı \& Nazik, 2004; cited in Demirbaş, 2016).

\subsection{Research Group}

The application universe of this research consists of Turkish teachers who teach Turkish as a foreign language abroad in the 2017-2018 academic year. The teachers who teach Turkish as a second language 
were tried to be reached on the internet and they were asked to return within 15 days. As a result of the study, 58 teachers participated in the questionnaire. 46 of the teachers participating in the survey are male and 12 are female.

\subsection{Data Collection Tools}

\subsubsection{Literature Study}

At the beginning of this study, it has been tried to scan the theses, articles, papers, congresses, conferences, and workshops on the teaching of Turkish as a foreign language in the digital environment, especially Google academic. While scanning, the words "teaching Turkish to foreigners, teaching Turkish, Newspaper in Education, (NIE)" constituted the basis of the search.

\subsubsection{Teacher Opinion Questionnaire}

One of the data collection tools in descriptive research is questionnaires. A questionnaire was applied to determine the role and place of newspapers in teaching Turkish as a foreign language and to get the opinions of teachers who are studying Turkish abroad. The questionnaire can be expressed as a data collection tool that is used to systematically determine in a short time the opinions of the people who make up a population or sample in order to find answers to the questions determined about a topic. While arranging the data obtained from the questionnaires, which are the simplest among the quantitative data collection tools and used to determine the opinions of individuals on a subject, the prevalence rate (frequency value), percentage and average score value of the data group are generally taken into consideration. In addition to these, processes such as t-tests, correlation and covariance analysis are performed on the data obtained from the tests, which are mostly used to determine the cognitive qualities of individuals (Metin, 2016).

While preparing the questionnaire, the literature was searched, the studies on the teachers and students' views on the use of the newspapers in the lessons were examined, and the topics to be included in the questionnaire were decided. A comprehensive study on this subject in the literature was conducted by Tangülü (2011), titled as "The Use Newspapers in the 8. Class Revolution History of the Republic and Kemalism and Related Teacher Feedback" (originally named as "8. Sinıf Türkiye Cumhuriyeti İnk1lâp Tarihi ve Atatürkçülük Dersinde Gazete Kullanımı ve Buna İlişkin Öğretmen Görüşleri”). After the questionnaire questions were adapted for Turkish, the opinions of an expert from Tshik University were taken. Following the expert opinion, the questionnaire was finalized by eliminating the deficiencies in the items. In the next phase, the questionnaire was sent via e-mail to teachers who teach Turkish abroad. The purpose of conducting the survey on the internet is to reach more participants. Data were collected from Turkish teachers who participated in the study for two weeks.

The questionnaire on teachers' opinions consists of three parts. In the first part, personal information about teachers, in the second part, there is a multiple-choice question to determine the lesson tools teachers use mostly in their lessons and a Likert-type questionnaire about the use of newspapers in Turkish lessons. Finally, in the third part, there is an open-ended question that states the opinions that teachers want to add on the use of newspapers. In this section, the first letters of the teachers' names and surnames were used to indicate the opinions of the teachers who participated in the survey. 


\subsubsection{Reliability of the Teacher Opinion Questionnaire}

There is a total of 12 questions in the questionnaire, which measures teachers' opinions on the use of newspapers in teaching Turkish to foreigners. The reliability of the questionnaire was calculated based on the answers given by the participants to these questions.

Reliability can be calculated in various ways, but the most widely accepted measurement in field studies for evaluating the internal consistency of a scale is the Cronbach's Alpha coefficient (Price \& Mueller, 1986), which tells how well items measure the same structure. As a result of the analysis with SPSS, the internal consistency coefficient of the questionnaire was calculated as 0.81 . The minimum acceptable value for the Cronbach Alpha is 0.70. Below this value, internal consistency is considered low. The value calculated as 0.81 shows high internal consistency (Best \& Kahn, 2006).

\subsection{Data Analysis}

The frequencies and percentages of the items in the teacher opinion questionnaire were calculated. The relationship between teachers' views and teachers' ages and teachers' experiences was determined by the Pearson correlation coefficient. The change of teachers' views according to gender was analyzed by independent group t-tests.

\section{Findings}

According to the results obtained from personal information in the first part of the questionnaire, $79.31 \%$ of the teachers participating in the study are male and $20.69 \%$ are female subjects. A ratio in favor of men can be mentioned in the distribution of the participants.

The answers to the question regarding the professional seniority of the teachers participating in the study are as follows. $22.41 \%$ of the teachers participating in the study have the experience for $1-3$ years, $32.76 \%$ for $4-8$ years, $37.93 \%$ for $9-15$ years and $6.90 \%$ for more than 15 years. According to the distribution, it is observed that teachers with experience between 4-8 and 9-15 years are close to each other and their rates are equal, while there is no equality in the other groups.

The distribution of the findings regarding the answers given to the question of the teachers participating in the study to reveal the type of school they graduated from is shown as follows. $37.93 \%$ (22) of the teachers participating in the study stated that they were graduates of the Faculty of Education, $10.34 \%$ (6) of the Faculty of Arts and Sciences, 44.83\% (26) of them had Master degree and 6.90\% (4) of them had $\mathrm{PhD}$ degree. As can be understood from the distribution, a ratio in favor of the Faculty of Education and Postgraduate participants is observed.

In the questionnaire applied to teachers, after personal information, they were asked which materials they used the most in their lessons. Teachers were asked to score between 1 and 10 to what extent they used each of the textbook, workbook, interactive $\mathrm{CD}$, poster, flash card, story books, newspaper, magazine, model, and brochure in their lessons. 


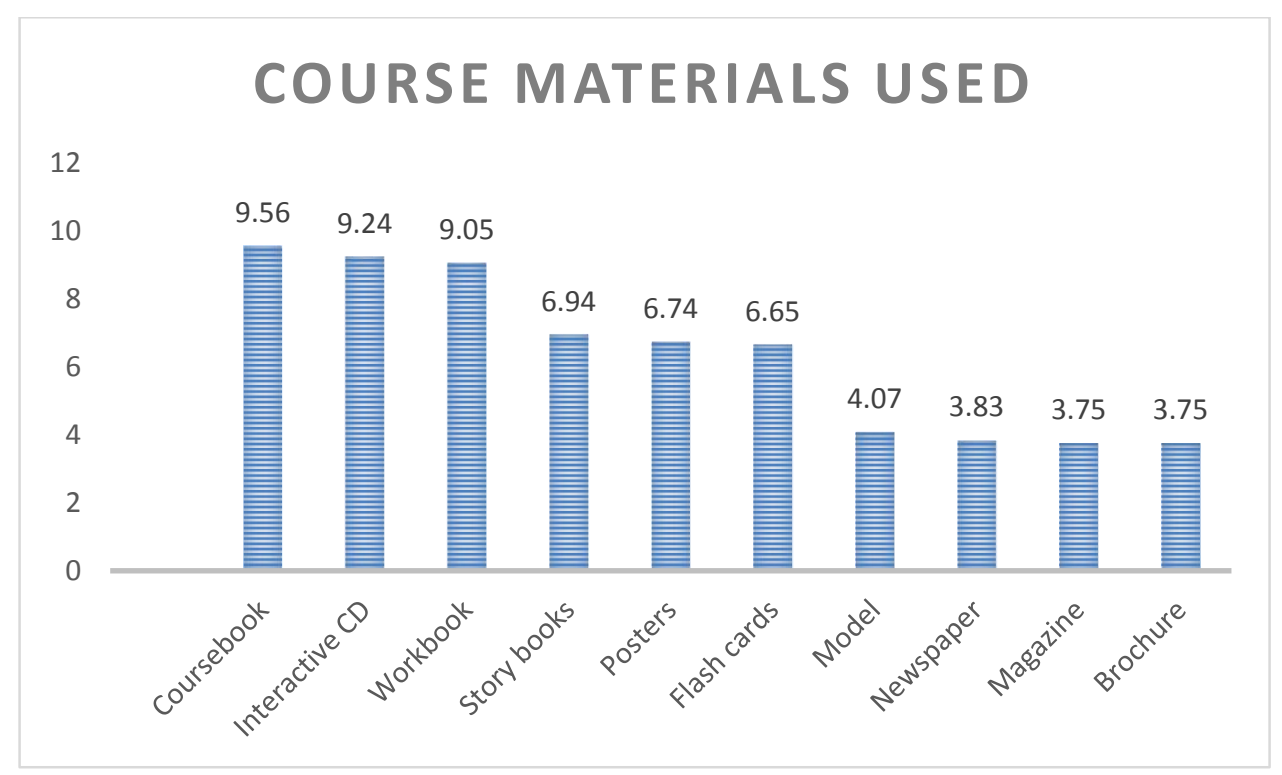

Figure 1: Distribution of materials used by Turkish teachers in lessons

It is observed that the participants scored these course materials out of 10 as 9.56, 9.05, 9.24, 6.74, 6.65, $6.94,3.83,3.75,4.07$ and 3.75, respectively. According to this, it is seen that participant teachers used most textbooks and interactive CDs as course materials while teaching Turkish to foreigners, and at least magazines and brochures.

\subsection{Analysis Based on Items}

The items of the questionnaire containing the opinions about the use of newspapers as a teaching tool and the percentages of the answers given to these items are shown in Table: 1. These two options are combined as "strongly agree" and "agree" express positive opinions. Similarly, since "disagree" and "strongly disagree" express negative opinions, these two options are combined. 
Table 1: Frequency and percentage table of the survey items

\begin{tabular}{|c|c|c|c|c|}
\hline No & Item & $\begin{array}{l}\text { Positive } \\
(\%)\end{array}$ & $\begin{array}{l}\text { Neutral } \\
(\%)\end{array}$ & $\begin{array}{l}\text { Negative } \\
(\%)\end{array}$ \\
\hline 1. & $\begin{array}{l}\text { Newspapers cannot be a lesson tool in teaching } \\
\text { Turkish to foreigners. }\end{array}$ & $21(36)$ & $16(28)$ & $21(36)$ \\
\hline 2. & $\begin{array}{l}\text { It is necessary to use newspapers in teaching Turkish } \\
\text { to foreigners. }\end{array}$ & $43(74)$ & $10(17)$ & $5(9)$ \\
\hline 3. & $\begin{array}{l}\text { It will be useful to use newspapers in teaching } \\
\text { Turkish. }\end{array}$ & $50(86)$ & $7(12)$ & $1(2)$ \\
\hline 4. & $\begin{array}{l}\text { Using newspapers in teaching Turkish to foreigners } \\
\text { increases students' interest and curiosity in Turkish } \\
\text { lessons. }\end{array}$ & $42(72)$ & $7(12)$ & $9(16)$ \\
\hline 5. & $\begin{array}{l}\text { Using newspapers in teaching Turkish to foreigners } \\
\text { does not improve students' language skills. }\end{array}$ & $31(53)$ & $9(16)$ & $18(31)$ \\
\hline 6. & $\begin{array}{l}\text { Using newspapers in teaching Turkish to foreigners } \\
\text { improves students' reading skills. }\end{array}$ & $53(91)$ & $3(5)$ & $2(3)$ \\
\hline 7. & $\begin{array}{l}\text { Using newspapers in teaching Turkish to foreigners } \\
\text { does not improve students' writing skills. }\end{array}$ & $27(47)$ & $9(16)$ & $22(38)$ \\
\hline 8. & $\begin{array}{l}\text { Using newspapers in teaching Turkish to foreigners } \\
\text { improves students' speaking skills. }\end{array}$ & $48(83)$ & $4(7)$ & $6(10)$ \\
\hline 9. & $\begin{array}{l}\text { Using newspapers in teaching Turkish to foreigners } \\
\text { does not improve students' listening skills. }\end{array}$ & $23(40)$ & $10(17)$ & $25(43)$ \\
\hline 10. & Newspapers improve students' vocabulary. & $53(91)$ & $2(3)$ & $3(5)$ \\
\hline 11. & $\begin{array}{l}\text { Using newspapers in teaching Turkish to foreigners } \\
\text { develops a culture of tolerance of the students. }\end{array}$ & $33(57)$ & $16(28)$ & $9(16)$ \\
\hline 12. & $\begin{array}{l}\text { Newspapers do not help students get to know the } \\
\text { culture of the target language. }\end{array}$ & $33(57)$ & $4(7)$ & $21(36)$ \\
\hline & Average & $38(66)$ & $8(14)$ & $12(20)$ \\
\hline
\end{tabular}

Items $1,5,7,9,12$ in the questionnaire are coded in reverse.

As seen in Table 1, while $66 \%$ of the participants were positive and $14 \%$ were neutral, $20 \%$ did not view the use of newspapers as a teaching tool. Among the questionnaire items, the sixth (using newspapers in teaching Turkish to foreigners improves students' reading skills) and tenth items (Newspapers improve students' vocabulary) received the most positive opinions, while the ninth item (using newspapers in teaching Turkish to foreigners does not improve students' listening skills) received the most negative opinions. The items in the first and eleventh (28\%) were the items that the participants were most hesitant about using newspapers as a teaching tool. 
The answers to the questionnaire are scored out of 5. The average score of the teachers was calculated as 4.10. Accordingly, it can be said that in general, teachers have a positive view of using newspapers in teaching Turkish to foreigners.

\subsection{Relationship between Age and Teachers' Views}

The ages of 58 teachers who participated in the survey ranged from 27 to 47 and their average age was 34 . The relationship between age and teachers' opinions was calculated with the Pearson correlation coefficient. The normal distribution of the data, which is one of the prerequisites to calculate the Pearson correlation coefficient, was controlled by creating a histogram. As seen in Figure 2, both teachers 'ages and teachers' opinions have normal distribution.
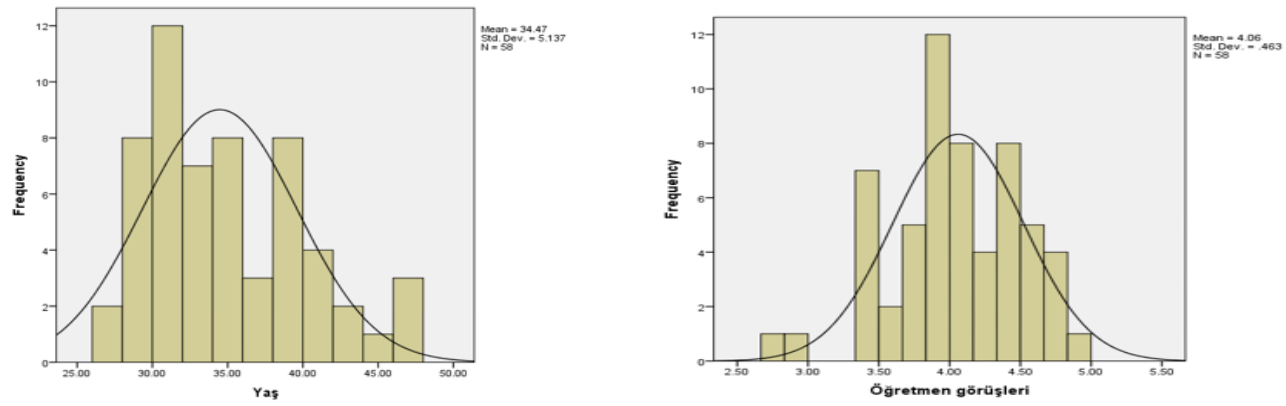

Figure 2: Teacher ages and distribution of teachers' opinions

According to the results of the Pearson correlation analysis, a correlation of $r=0.154$ was found between teachers 'ages and teachers' opinions. This correlation was not statistically significant ( $p>0.05$ ). Accordingly, it can be said that there is no relationship between teachers 'views on the use of newspapers in teaching Turkish to foreigners and teachers' ages.

\subsection{The Relationship between the Number of Years of Teaching Turkish to Foreigners and Teachers' Views}

The Turkish teaching years of the teachers participating in this study were divided into four categories as 1-3, 4-8, 9-15 and 15 and above. The relationship between the number of years of teaching Turkish and the views of teachers was calculated using the Spearman Brown rank difference correlation coefficient technique. With this technique, the linear relationship between two variables measured using ordinal scores is explained. In this study, one of the data is categorical (the number of years of teaching Turkish) and the other (teachers' opinions) is continuous. The relationship between these two variables was calculated by the Spearman Brown rank differences correlation method (Bartko, 1976: 762-765).

According to the Spearman Brown rank differences correlation analysis, a correlation of $r=-0.043$ was found between the number of years of teaching Turkish and the views of teachers. This correlation was not statistically significant ( $p>0.05$ ). Accordingly, it has been observed that there is no relationship between teachers' views on using newspapers in teaching Turkish to foreigners and the number of years of teachers teaching Turkish. 


\subsection{Relationship between Gender and Teachers' Views}

Of the 58 teachers participating in the study, 12 are female (21\%) and 46 are male (79\%). The difference between the opinions of male and female teachers was analyzed by independent group t-tests. The results of this analysis are shown in Table: 4.1.5.3. The precondition for equality of variances required to conduct the independent groups t-test was checked with the Levene's Test. Accordingly, it was seen that the variances were not significantly different from each other $(p=0.487)$.

Table 2: T-test results for the relationship between gender and teachers' opinions.

\begin{tabular}{|l|l|l|l|l|l|}
\hline $\begin{array}{l}\text { Levene's Test for } \\
\text { Equality of Variances }\end{array}$ & \multicolumn{4}{l|}{ T-test for equality of means } \\
\hline $\mathrm{F}$ & $\mathrm{p}$ & $\mathrm{t}$ & $\mathrm{df}$ & $\mathrm{p}$ & $\begin{array}{l}\text { Difference } \\
\text { of means }\end{array}$ \\
\hline 0.490 & 0.487 & -1.394 & 56 & 0.169 & -0.20 \\
\hline
\end{tabular}

The average opinion of female teachers out of 5 who participated in the study was calculated as 3.90 and that of male teachers was 4.10 . The difference of 0.20 between these opinion points was not found significant according to the t-test analysis ( $p>0.05$ ). Apparently, there is no significant relationship between gender and teachers' views.

\subsection{Teacher Opinions}

In the teacher opinions questionnaire, the teachers asked, "What are your views on the usefulness and limitations of using newspapers in teaching Turkish to foreigners?" The answers given by the teachers participating in the research to the open-ended question were collected under the following headings: Motivation, views on language skills, culture and art, views on the nature of newspapers and views on the use of newspapers.

Motivation: Newspapers will attract students' attention as they are updated every day. Since each page is full of different news, pictures, information, entertainment, etc., it will increase students' participation in the lesson while being used in the lesson. It will help us attract the attention of students.

"We can use newspapers occasionally to attract attention. I think it will not work in any other way. " DM “..... newspapers arouse interest in students if they are given selectively. In addition, it can be ensured that the target culture is taught from different angles through newspapers. " YO

Views on language skills: The use of newspapers in Turkish lessons primarily improves reading and comprehension skills. It helps the development of vocabulary. It helps to memorize fluent speech and fixed expressions. The daily life of the target language is learned using newspapers. Thanks to the newspapers, the daily language can be mastered. It accelerates the integration into the target society while improving the general knowledge of the students. It improves comprehension skills and makes self-expression easier. Thanks to different perspectives, their ability to analyze events improves. 
"The newspaper plays a role in developing writing and reading skills. Publishing and reading newspapers make a fun addition to the lesson. " TI

"It has a great contribution to the increase of students' vocabulary knowledge and their writing skills, especially to the development of reading comprehension skills. Especially, the student who has improved vocabulary skills will be able to speak better, learn to write and speak Turkish in a regular way. " DD

Culture and art: Newspapers will particularly attract attention to the culture of the target language. Cinema and magazine world are closely followed in line with the popularity of the target culture from the country you live. This will support the development of the language skills of the students who read the arts and culture pages in line with the students' interests. The culture of the target language will be handled from different angles through the newspapers. Newspapers can create tolerance and awareness towards different cultures.

"Newspapers will be useful as they are not uniform. Since each page is different, it is valuable for foreigners in terms of vocabulary. I think that especially the culture - art part will be useful for students .... New words are very useful for learning ... "EG

“........... can only be used to promote Turkish culture. "LT

Views on the nature of newspapers: Newspapers are mostly tools that support a political idea. The accuracy of the news in the newspapers has always been a matter of debate. They are new and cheap materials.

"In general, we teach Turkish at high school level and the contents in the newspapers are not very interesting for this age...." BC

"It can be useful in general, but I don't think it is exactly an effective method. With the development of technology, more technological materials should be used and developed for today's students. Only in this way will Turkish education be useful and effective. " HE

Views on newspaper use: It can be used in the preparation stage to attract attention in the lesson. Text and pictures suitable for the level should be used. It should not cause a negative attitude towards the target language and culture. The materials to be used should be chosen carefully. Text and pictures that will serve as bad examples should not be used. It can be used at high school level.

"It should be general culture and current issues, but not a political and hatred thought." OS

"It should be used but should be selective and difficult titles should not be chosen. ...." ŞS

"Newspapers will benefit and it will be more effective if topics that appeal to all age groups are included in the sections of the newspapers." MG

Negative opinions about the use of the newspaper: In addition to the positive opinions above, some negative opinions about the use of the newspaper in the lessons were also expressed. It will not be beneficial except for attracting attention to the lesson, that there is no method for using newspapers in Turkish teaching lessons, that the supply of newspapers is difficult, time is not enough, cannot be used at 
the beginner level, but can be used at B2, C1-C2 levels, it will give unnecessary information to the student. He may consider reading newspaper as unnecessary because he lives in a new generation digital world.

There were also teachers who stated that it would be difficult to read a newspaper.

"Using the newspaper in every lesson can be difficult. At least in some classes, newspapers can be brought to the class at certain times and presented to students for examination. " CÖ

“............. Since the lesson hours are short, it will not be enough even if you want to use it. LT

\section{Discussion and Conclusion}

According to the data obtained from the research, it was determined that the teachers participating in the study used textbooks and interactive CDs the most as course materials in teaching Turkish as a foreign language, and at least newspaper, magazine and brochure (Figure 1). One of the reasons why newspapers (3.83\%) are used very little in teaching Turkish as a foreign language is that all the teachers participating in the survey are not able to reach newspapers literally because they work abroad. In line with the openended questions asked to the teachers, the teachers' opinions that there is no such method in teaching Turkish as a foreign language may have revealed a low rate of using newspapers in lessons.

Moreover, based on teachers 'opinions, teachers' negative beliefs about the nature of newspapers and the biased publication of newspapers, as well as political developments in recent years may cause teachers not to consider newspapers among their first choices. However, the point on which teachers generally agree is that in teaching Turkish as a foreign language, newspapers will directly contribute to reading comprehension, vocabulary development, listening and speaking skills.

A study supporting the result of the newspapers in this study being preferred as less used course material was carried out by Özbay. Özbay (2003) found that $94.44 \%$ of the teachers preferred textbooks as primary material in their lessons in a study conducted with 108 teachers to determine the current status of Turkish teaching in terms of equipment and materials. In the mentioned study, the rate of using newspapers, magazines, visual and audio tools as the least used lesson materials by teachers was $5.53 \%$. That result seems close to the result of this research. In this study, it is seen that Turkish teachers use newspapers, magazines, and brochures at the lowest level.

One of the findings of the study is that teachers have a positive view of using newspapers in teaching Turkish as a foreign language. Foreign language lessons should be supported by the cultural environment of the target language. For this purpose, visual materials should be used in lessons. Although textbooks are the primary material for a foreign language lesson, foreign language teachers feel responsible for using visual materials in their lessons.

In a study conducted by Dellal and Yücel (2015), 92.3\% of the teachers who participated in the questionnaire stated that the textbooks were not sufficient in terms of material use, they used visual materials that would develop four basic skills in their lessons (55.4\%), and the target language's cultural background. They reported that they used targeted materials and obtained these materials from the internet. 
The study conducted by Tangülü (2011) titled as "The Use Newspapers in the 8. Class Revolution History of the Republic and Kemalism and Related Teacher Feedback" was carried out with 440 teachers and almost $75 \%$ of them stated positive opinion about using newspapers in lessons. In a study by Arslan and Atış (2015), teachers who work in teaching Turkish as a foreign language stated that newspapers and magazines would be the most effective in the development of students' reading skills. This result is in accordance with the results obtained from the teacher opinions questionnaire by the researcher and the purpose of the research.

According to Celik (2018), Bozkurt (2010: 6) and Vockell and Cusick (1995), it is seen that teachers prefer the newspaper in their lessons for the following reasons:

- Students are motivated,

- Contributes to skill teaching in the classroom,

- Cheaper than books,

- The subject areas are diverse,

- Provides the ability to look at the world from a real window

- Improves writing skills.

One of the findings of this study is that there is no relationship between teachers 'views and teachers' ages in the use of newspapers to improve reading skills in teaching Turkish as a foreign language. The average age of teachers participating in this research is 34. Considering that the average graduation year of the teachers participating in the survey is 2000 and later, it can be assumed that the teachers received lesson material development and adaptation training during their four-year faculty education. Teachers believe in the use of supplementary materials, including newspapers, in their lessons.

Another finding of this study is that there is no relationship between teachers' views on the use of newspapers in teaching Turkish as a foreign language and their experiences of teaching Turkish. In the study conducted by Tangülü (2011), no significant difference was found between the teachers' professional experience of using newspaper in lessons and their views on using newspaper. The results of this study coincide with the views of the teachers about the use of newspapers in teaching Turkish to foreigners. Every year has a value in the education and training life of teachers. Teachers who have completed their first year of teaching or who have fifteen or more professional experience agree that newspapers can be used as a teaching tool to improve reading comprehension skills. Today's teachers are aware of modern technology and they are of the same opinion because of their belief in the necessity of enriching the lessons with audio-visual materials.

Another result of the study is that there is no significant relationship between the genders of teachers and their views on the use of newspaper in teaching Turkish as a foreign language. When the literature was examined, in the study conducted by Tangülü (2011), it was pinpointed that male teachers had a more positive view of using newspapers in lessons compared to female teachers, and it is because of the reason was that male teachers read more newspaper. 


\section{Conclusion}

Although the books have preserved their place as one of the course materials in teaching Turkish as a foreign language, researchers have sought supplementary materials to improve students' language skills that fit the spirit of the time. One of these materials called authentic materials is newspapers. It is possible to list the results of this study, which was conducted to determine the teachers' views on the use of newspapers as a course material in teaching Turkish as a foreign language as follows:

1. In the study, it was concluded that the teachers used the other supplementary materials that came with the textbooks as the most used course material in their lessons.

2. Most of the teachers who took part in teaching Turkish as a foreign language and participated in the study agree on the view that newspapers can be used as a teaching tool in teaching Turkish as a foreign language. This consensus is one of the positive results of the research.

3. Teachers who took part in teaching Turkish as a foreign language and participated in the study believed that the use of newspapers in Turkish lessons would positively contribute to students' reading comprehension and vocabulary skills, which is another positive result of the study.

4. The absence of a relationship between the ages of the teachers who took part in teaching Turkish as a foreign language and participated in the study and their views on the use of newspapers as a teaching tool can be seen as another positive result of the study.

5. Another positive result of the study is that there is no relationship between the seniority of the teaching profession of the teachers who took part in teaching Turkish as a foreign language and their views on using newspaper to improve their reading comprehension skills in Turkish lessons. The teacher who is new to the profession and the teacher with many years of experience in this profession also have a positive opinion that newspapers can be used in Turkish lessons.

6. When the teachers who took part in teaching Turkish as a foreign language and participated in the research are evaluated in terms of gender, it seems that they shared the same opinion that newspapers can be used in Turkish lessons, which can be expressed as another positive result of the study. Male and female teachers believe that reading comprehension skills of students will improve in Turkish lessons that are taught with newspaper activities.

7. Teachers participating in the study stated that the use of newspapers in Turkish lessons increased students' participation and motivation. It is one of the positive results of the research that Turkish lessons organized with newspaper activities will increase the motivation of the students. Students with increased motivation enjoy the learning environment and are satisfied with their learning. This satisfaction also positively affects the attitude towards the lesson. Findings obtained from interviews with the experimental group also support this result. As one of the important results of the research, it can be stated that newspaper activities in Turkish lessons positively affect the motivation of the students.

8. Teachers who took part in teaching Turkish as a foreign language and participated in the study believe that Turkish lessons taught with newspaper activities will improve students' reading comprehension and vocabulary, and will have a positive effect on their speaking skills by memorizing fixed expressions. Comparing the post-test scores of the experimental and control groups who teach Turkish lessons with newspaper activities, the difference in points in favor of the experimental group shows that newspapers have a positive and permanent effect on students' reading comprehension and vocabulary skills. 
9. Teachers who took part in teaching Turkish as a foreign language and participated in the research believe that Turkish lessons taught with newspaper activities are more enjoyable and the students participate more eagerly. This view is also supported by the results obtained from the student interview with the experimental group. As a result, it is one of the important results of the study that Turkish lessons taught with newspaper activities increase the participation of students in the lessons and make the lessons more enjoyable.

10. Another positive result obtained from the teacher opinions questionnaire and student interviews is that the teachers believe that students develop awareness of Turkish language and culture in Turkish lessons taught through newspaper activities.

11. Teachers participating in the research show that they are concerned about the use of newspapers in Turkish lessons as they have political content. Teachers who consider using newspapers as a lesson in their Turkish lessons should be careful about this issue, and they need to consider this point when using the newspaper in the lessons, as this issue was handled by Yahşi and Keleş (2013) (cited in Dönmez \& Yazıc1, 2008).

\section{Suggestions}

Teachers who take part in teaching Turkish as a foreign language can inspire other colleagues by sharing experiences on newspaper use activities in their lessons on different social platforms. A Turkish web page can be created for the use of newspaper in lessons. Thanks to this page, a pool of newspaper usage can be created, and Turkish teaching can be enriched.

\section{References}

Arslan, M., \& Atış, S. (2015). Yabanc1lara Türkçe öğretiminde dilsel becerilerin gelişimine etkisi bakımından ders materyallerinin önem derecelerinin analitik hiyerarşi süreci (AHS) İle Belirlenmesi. Bartın Üniversitesi Eğitim Fakültesi Dergisi, 4(2), 711-726. doi:Doi: 10.14686/buefad.v4i2.5000138861

Bartko, J. J. (1976). On various intraclass correlation reliability coefficients. Psychological Bulletin, 83(5), 762-765. doi:http://dx.doi.org/10.1037/0033-2909.83.5.762

Best, J. W., \& Kahn, J. V. (2006). Research in education (10th ed. b.). New York: Pearson Education Inc.

Bozkurt, E. (2010). Ilkögrretim 5.sinif fen ve teknolojidersi"maddenin değişimive taninmasi" ünitesinde gazetelerden yararlanilarak hazirlanan ders etkinliklerinin tutum, başari ve eleştirel düşünme becerilerine etkisi. Kocaeli: Kocaeli Üniversitesi Fen Bilimleri Enstitüsü.

Carey, H., \& Greenberg, J. (1991). How to read a newspaper (A social studies skills book). New York: Library of Congress Catologing in Publication Daha.

Celik, B. (2018). Improvement of reading skills in the second foreign language courses by the "antimethod" way. International Journal of English Linguistics, 8(4), 237-252.

Celik, B. (2020). The perceptions of foreign language pre-service teachers towards multicultural education: Case of the faculty of education, TIU-Erbil, Iraq. International Journal of English Linguistics, 10(1).

Celik, B., \& Yildı, Y. (2019). The role of foreign language culture on teaching the language and learner motivation. International Journal of Social Sciences \& Educational Studies, 5(4), 215-223.

Dellal, N. A., \& Yücel, M. S. (2015). Yabanci dil öğretmenlerinin derslerinde materyal kullanimina ilişkin tutum ve görüşleri. International Periodical For The Languages, Literature and History of Turkish or Turkic, 10(2), 1051-1066. http://dx.doi.org/10.7827/TurkishStudies.7950 
Demirbaş, M. (2016). Bilimsel araştirma ve özellikleri. m. mustafa içinde, kuramdan uygulamaya eğitimde bilimsel araştirma yöntemleri (s. 11). Ankara: Pegem Akademi.

Haim, O. (2018, 03 23). Using The Newspaper In The EFL Classroom. pubhtml5/com/mqtt/jhie/basic adresinden alind.

Hammer, J. (2003). The practice of English language teaching, Third Edition. New York: Longman.

Herald, T. P. ( 8 June 1795). Consider using the 1795 quotation, or this entire history, in your teacher workshop.

İçel, K. (1983). Devletle basın arasındaki karşılıklı ilişkiler: Basın ve basın karşıtlığı hukuki sorunlar. İstanbul: Hürriyet Vakfı Eğitim Yayınları.

Kaptan, S. (1998). Bilimsel Araştırma ve İstatistik Teknikleri. Ankara: Tekışı Ofset.

Kossack, S. (1987). Use The News- NIEWEEK. AWPA: Resourch for Reading. Journal of Reading 306.

Mart, Ç.T. (2013a). A passionate teacher: Teacher commitment and dedication to student learning. International Journal of Academic Research in Progressive Education and Development, 2(1), 437-442.

Mart, Ç.T. (2013b). Commitment to school and students. International Journal of Academic Research in Business and Social Sciences, 3(1), 336-340.

Mart, Ç.T. (2017). Literary texts: A means to promote language proficiency of upper-intermediate level EFL students. Journal of Education in Black Sea Region, 2 (2), 44-55.

Metin, M. (2016). Nicel veri toplama araçları. M. Metin, \& M. Metin (Dü.) içinde, Kuramdan uygulamaya eğitimde bilimsel araştırma yöntemleri (3. Ed. b., s. 161-214). Ankara: Pegem Akademi.

Moparthi, S. B. (2014). Authentic texts as pedagagic tools in English language classroom. Scholar Critic, 1(01), 54-71.

Newton, K. (1985). Newspaper in education: New readers.

NIE: Getting Started A Guide for Newspaper In Education Programs. (2005; 7-8). J. Abbott (Dü.). $\mathrm{V}$ i e n na: N A A F o u n a t i on.

Numan, D. (1988). Principle for designing language teaching materials. Guideline.

Özbay, M. (2003). Türkçe öğretiminde hedef-amaç ilişkisinin ders kitabı öğrenğinde değerlendirilmesi. TÜBAR-XIII-, 63.

Öztürk, B. K. (2016). Yabancı dil olarak Türkçe öğretiminde materyal tasarımı -süreç ve etkinlikler-. F. Yıldırım, \& B. Tüfekçioğlu içinde, Yabancı Dil Olarak Türkçe Öğretimi Kuramlar-YöntemlerBeceriler-Uygulamalar. Ankara: Pegem Akademi.

Pillai, A. (2006; 71). Scholl essey Letters and Phrases. New Delhi-2: Loyus Press.

Planc1, H. (2011). Türkçe ses bilgisi. Eskişehir: Anadolu Üniversitesi Yayını No 2362.

Price, J. L., \& Mueller, C. W. (1986). Handbook of organizational measurement. Marshfield, MA: Pitman Publishing.

Püsküllüoğlu, A. (1994). Arkadaş Türkçe sözlük. Ankara: Arkadaş.

Serin, H. (2017). Teaching about Respect and Tolerance with Presentations on Cultural Values. International Journal of Social Sciences \& Educational Studies, 3(4), 174.

Stone, G. (1988). Measuring adult readership potential of the newspaper in education program. Newspaper Research Journal 9(2).

Street, C. (2002). Teaching with newspaper. The Social Studies, 93(3), 131-133. doi:doi/abs/10.1080/00377990209599897

Tangülü, Z. (2011). 8. sinif Türkiye Cumhuriyeti inkilâp tarihi ve Atatürkçülük dersinde gazete kullanimi ve buna ilişkin ögretmen görüşleri. Ankara: Gazi Üniversitesi eğitim bilimleri enstitüsü.

Tokgöz, O. (1973; 83). Günümüzde gazeteler ve gazete okuma. http://dergipark.ulakbim.gov.tr/ausbf/article/view/5000054216/5000051531.

Ulusoy, M. (2009). Boşluk tamamlama testinin okuma düzeyini ve okunabilirliğiölçmede kullanilmasi. Türk Ĕgitim Bilimleri Dergisi, 7(1), 105-126. 
Vural, A. M. (2000). Medyanın kültürel kalkınmayı sağlama ve eğitim işlevi. İstanbul Üniversitesi İletişim Fakültesi Dergisi. www.journals.istanbul.edu.tr/iuifd/article/.../1019012871. adresinden alind 1

Yahşi, İ., \& Keleş, H. (2013). Tarih öğretiminde gazete kullanımının çok perspektifliğe etkisi. Kastamonu Eğitim Dergisi, 694-710.

Yildiz, Y., \& Celik, B. (2017). Commitment to the teaching profession. International Journal of Social Sciences \& Educational Studies, 4(2), 93.

Yildiz, Y. (2016). The role of extracurricular activities in the academic achievement of English as foreign language (EFL) students In Iraqi universities (A case of Ishik University preparatory school). Unpublished PhD Thesis. Tbilisi: International Black Sea University.

Yildiz, Y. (2020). Reading habit and its role on students' academic success at language preparatory school: A research on Tishk International university preparatory school students. Amazonia Investiga, 9(27), 189-194. 